\title{
Pengaruh Kepemimpinan, Fokus pada Konsumen, Pemberdayaan Karyawan, dan Manajemen Proses terhadap Kepuasan Kerja Karyawan PT Telkomsel Area Pekanbaru
}

\author{
Febriwanti $^{*}$, Zulfadil², dan Samsir ${ }^{2}$ \\ ${ }^{1}$ Mahasiswi Program Pasca Sarjana Fakultas Ekonomi, Universitas Riau \\ ${ }^{2}$ Dosen Pasca Sarjana Fakultas Ekonomi, Universitas Riau.
}

\begin{abstract}
Abstrak Penelitian ini bertujuan untuk mengetahui bagaimana pengaruh kepemimpinan, fokus pada konsumen, pemberdayaan karyawan dan manajemen proses terhadap kepuasan kerja karyawan PT. Telkomsel Pekanbaru. Populasi dalam penelitian ini adalah semua karyawan tetap di PT. Telkomsel Pekanbaru yang berjumlah 123 orang. Pengambilan sampel dilakukan dengan rumus slovin sehingga diperoleh jumlah sampel sebanya 94 orang. Analisis data yang digunakan adalah deskriptif kuantitatif dengan metode regresi linier berganda dengan bantuan program SPSS dan Uji Beda T-Test. Dari hasil pengujian yang telah dilakukan diketahui bahwa Kepemimpinan, fokus pada konsumen, pemberdayaan karyawan dan manajemen proses secara simultan dan parsial berpengaruh terhadap kepuasan kerja karyawandi PT. Telkomsel Pekanbaru. Kepuasan kerja karyawan laki-laki dan perempuan relative tidak berbeda, walupun secara rata-rata kepuasan kerja karyawan perempuan lebih tinggi dari kepuasan kerja karyawan laki-laki. Perbedaan tersebut ditunjukkan dengan orientasi dimana kepuasan kerja karyawan laki-laki terletak pada tugas yang dikerjakan dan motivasi yang diberikan atasan, sedangkan orientasi kepuasan kerja karyawan perempuan ada pada besaran gaji, peluang promosi dan interaksi antar karyawan di dalam perusahaan. Pimpinan perusahaan harus memperhatikan sistem gaji dan promosi yang telah ada karena karyawan yang berjenis kelamin laki-laki menganggap bahwa sistem gaji dan promosi belum dapat memuaskan kerja, selain itu pimpinan juga perlu memperhatikan bagaimana hubungan interaksi yang ada baik itu karyawan dengan karyawan maupun karyawan dengan pimpinan sehingga kepuasan kerja dapat meningkat.
\end{abstract}

Kata kunci: Kepemimpinan, Fokus Pada Konsumen, Pemberdayaan Karyawan, Manajemen Proses, Kepuasan Kerja.

Abstract This study aims to determine how the influence of leadership, customer focus, employee empowerment and process management on employee job satisfaction PT. Telkomsel Pekanbaru. The population in this study were all employees at PT. Telkomsel Pekanbaru totaling 123 people. Sampling was done by slovin formula in order to obtain a sample sebanya 94 people. Analysis of data is descriptive quantitative with multiple linear regression method with SPSS and different test of T-Test. From the test known the leadership, customer focus, employee empowerment and

E-mail penulis koresponden: febriwanty.marwan@gmail.com 
management processes simultaneously and partially influence on job satisfaction karyawandi PT. Telkomsel Pekanbaru. Employee satisfaction male and female relative is no different, even though the average female employee job satisfaction is higher than job satisfaction of male employees. The differences are indicated with an orientation in which the orientation of employee satisfaction in men are located on the task at hand and motivation given employer, while the female employee job satisfaction orientation is in the amount of salary, promotion opportunities and interaction between employees in the company. Company leaders must pay attention to the system of salaries and promotions that have been there since the employee-sex male considers that the system of pay and promotion can not satisfy the work, besides leaders also need to consider how the interaction you may have on employees with employees and employees with leadership so that job satisfaction can be increased.

Keywords: Leadership, Customer Focus, Employee Empowerment, Process Management, Job Satisfaction.

\section{PENDAHULUAN}

Dalam perkembangan dunia usaha, hendaknya organisasi mampu memberikan arahan yang positif terhadap seluruh karyawannya demi mencapai tujuan organisasi. Perusahaan yang siap berkompetisi harus memiliki manajemen yang efektif, yang mampu mengelola seluruh sumberdayanya termasuk sumber daya manusia yang ada dalam perusahaan tersebut. Untuk itu dibutuhkan manajemen yang efektif dengan dukungan pemimpin yang cakap dan kompeten di bidangnya.

Permasalahan sumberdaya manusia sebenarnya dapat dianalisa dari dua aspek, yakni dari aspek kuantitas dan aspek kualitas. Dari aspek kuantitas, potensi sumberdaya manusia Indonesia relatif sangat besar mengingat jumlah penduduknya sangat banyak. Namun dari aspek kualitas, Indonesia masih mengalami kekurangan tenaga kerja (SDM) yang berkualitas sesuai dengan tuntutan jabatan dan profesi pekerjaan.

SDM merupakan salah satu aspek yang kompleks, dikarenakan banyak faktor yang dapat mempengaruhi kualitas SDM dalam suatu perusahaan. Salah satunya dengan meningkatkan kepuasan kerja karyawan. Setiap perusahaan selalu mengharapkan kepuasan kerja karyawannya sangat tinggi, karena dengan memiliki kepuasan kerja yang tinggi maka karyawan tersebut akan memberikan sumbangan yang optimal bagi perusahaan. Perusahaan yang siap berkompetisi juga harus memiliki manajemen yang efektif dan dalam mengelola sumberdayanya.

Sebab itulah perhatian akan kepuasan kerja karyawan penting artinya menjadi prioritas untuk dijadikan panutan guna mencapai tujuan perusahaan. Kepuasan kerja mencerminkan perasaan seseorang terhadap pekerjaan dan 
segala sesuatu yang ada di lingkungan kerjanya. Setiap pemimpin perusahaan berusaha untuk menciptakan kepuasan kerja bagi para karyawannya, karena kepuasan kerja merupakan faktor yang diyakini dapat mendorong dan mempengaruhi semangat kerja karyawan agar karyawan dapat bekerja secara baik.

Untuk perusahaan besar seperti PT Telkomsel Pekanbaru yang merupakan suatu perusahaan yang bergerak dalam bidang jasa Telekomunikasi. Dimana perusahaan ini menyediakan sarana dan jasa layanan telekomunikasi dan informasi kepada masyarakat luas sampai kepelosok daerah di seluruh Indonesia. Telkomsel merupakan perusahaan telekomunikasi dengan pangsa pasar terbesar di Indonesia. Tentunya perusahaan ini memiliki tatakelola manajemen yang baik.Namun untuk Area distribusi Pekanbaru sendiri telkomsel harus bersaing ketat dengan provider lainnya terutama untuk penggunaan paket data internet. Masalah ini bisa saja disebabkan karena masalah internal atau masalah eksternal, seperti masalah pada sumber daya manusianya.

Oleh karenanya menjadi menarik untuk mengamati, bagaimana cara Telkomsel Area Pekanbaru dapat mengoptimalkan kemampuan karyawan untuk dapat secara bersama-sama meningkatkan prestasi kerja dengan kinerja yang baik nampaknya masih menjadi tugas bersama bagi manajemen Area Pekanbaru sendiri dan tentunya para karyawannya.

Menurutnya kepuasan kerja juga dapat diukur dengan kedisiplinan, moral kerja, dan labour turnover yang kecil, maka secara relatif kepuasan kerja karyawan baik tetapi sebaliknya jika kedisiplinan, moral kerja dan labour turnover besar, maka kepuasan kerja karyawan pada suatu perusahaan dinilai kurang.

Menurutnya kepuasan kerja juga dapat diukur dengan kedisiplinan, moral kerja, dan labour turnover yang kecil, maka secara relatif kepuasan kerja karyawan baik tetapi sebaliknya jika kedisiplinan, moral kerja dan labour turnover besar, maka kepuasan kerja karyawan pada suatu perusahaan dinilai kurang.

Berdasarkan survey yang dilakukan diketahui bahwa kepuasan kerja karyawan masih rendahterlihat dari banyaknya jumlah karyawan yang keluar dari perusahaan, baik yang mengundurkan diri maupun yang keluar tanpa alasan.

Saatmelakukan prasurvey awalterhadap 30 orang karyawan PT. Telkomsel Area Pekanbaru yang dilakukan secara acak. Ternyata yang menyebabkan kepuasan kerja karyawan salah satunya adalah faktor kepemimpinan. Hal ini sesuai dengan hasil penelitian yang dilakukan oleh Raharjo dan Nafisah (2006). Dari lima gaya kepemimpinan yang dianalisis ternyata semuanya berpengaruh terhadap kepuasan kerja karyawan. Seorang pimpinan harus mampu untuk memotivasi karyawannya secara aktif dan membantu menciptakan atmosfer yang mendorong, mendukung, dan mempertahankan perbaikan. Hasil survei yang dilakukan menujukkan bahwa persepsi karyawan terhadap kepemimpinan yang berlaku tergolong rendah. Sehingga diketahui masalah kepemimpinan sepenuhnya belum maksimal. 
Selain kepemimpinan, ternyata fokus pada konsumen atau pelanggan juga berpengaruh terhadap kepuasan kerja karyawan. Berdasarkan pada konsep bahwa setiap orang mempunyai pelanggan dan bahwa kebutuhan dan harapan pelanggan harus dipenuhi setiap saat, maka organisasi/perusahaan secara keseluruhan harus dapat memenuhi kebutuhan pelanggan eksternal (pembeli). Dari pernyataan karyawan diketahui bahwa fokus perusahaan terhadap konsumen masih rendah. Sehingga perusahaan belum sepenuhnya mampu memenuhi kebutuhan dan harapan para konsumennya.

Pemberdayaan karyawan juga berpengaruh terhadap kepuasan kerja karyawan. Pemberdayaan karyawan adalah proses memberikan karyawan kemampuan dan wewenang sehingga memudahkan karyawan untuk mengambil tindakan pribadi, berkarya dan perilaku yang memberikan kontribusi positif bagi misi organisasi. Pemberdayaan dapat meningkatkan komitmen kerja karyawan dan menghilhami perubahan yang membantu tujuan organisasi.

Selain faktor diatas, ternyata manajemen proses juga berpengaruh terhadap kepuasan kerja karyawan. Process management adalah seperangkat alat praktek kerja yang mengkombinasikan pendekatan metodologis dan pengelolaan sumber daya manusia, dan diimplementasikan guna mengelola serta meningkatkan proses produksi suatu perusahaan dalam menghasilkan produk barang dan jasa. Adapun praktek metodologis dari suatu manajemen proses bertujuan untuk mengelola dan meningkatkan aspek teknis dari suatu proses termasuk diantaranya adalah mengelola masukan atau input dan menghasilkan keluaran atau output hal ini berasal dari manfaat teori statistik mengenai variasi proses dalam proses pengendalian manajemen.

Adapun tujuan penelitian adalah: (1) Untuk mengetahui pengaruh kepemimpinan, fokus pada konsumen, pemberdayaan karyawan, dan manajemen proses terhadap kepuasan kerja karyawan. (2) Untuk mengetahui pengaruh kepemimpinan terhadap kepuasan kerja karyawan. (3) Untuk mengetahui pengaruh fokus pada konsumen terhadap kepuasan kerja karyawan. (4) Untuk mengetahui pengaruh pemberdayaan karyawan terhadap kepuasan kerja karyawan. (5) Untuk mengetahui pengaruh manajemen proses terhadap kepuasan kerja karyawan. (6) Untuk mengetahui perbedaan kepuasan kerja karyawan berdasarkan gender.

\section{TELAAH PUSTAKA}

\section{Kepuasan Kerja}

Kepuasan kerja menurut Robbins dalam Wibowo (2010) adalah sikap umum terhadap pekerjaan seseorang, yang menunjukkan perbedaan antara jumlah penghargaan yang diterima pekerja dan jumlah yang mereka yakini seharusnya mereka dapatkan. Kepuasan kerja akan mendukung tujuan organisasi. Dengan kepuasan kerja yang tinggi atau baik akan membuat karyawan semakin loyal kepada perusahaan atau organisasi. Karena 
penghargaan yang mereka dapatkan dari organisasi sesuai dengan yang mereka yakini sehingga mereka termotivasi untuk bekerja dan loyalitas mereka kepada organisasi akan semakin tinggi.

Menurut Anoraga (2009) kepuasan kerja mencerminkan perasaan seseorang terhadap pekerjaannya dan segala sesuatu yang dihadapinya dalam lingkungan kerjanya. Ada dua aspek yang ditekankan di sini, pertama adalah perasaan seseorang terhadap pekerjaannya, yang kedua adalah perasaan seseorang terhadap lingkungan kerjanya. Perasaan yang dimaksud berkaitan dengan kejiwaan (psikologis seseorang). Ini bermakna bahwa kepuasan kerja seseorang tidak hanya ditentukan oleh faktor pekerjaan itu sendiri tetapi juga ditentukan oleh aspek-aspek yang terkait dengan pekerjaan itu. Apabila aspekaspek tersebut sesuai dengan harapan seseorang maka dia akan merasa senang dan puas demikian pula sebaliknya.

Kepuasan kerja pada dasarnya adalah security feeling (rasa aman) yang dirasakan oleh karyawan, yang memiliki: (1) Segi sosial ekonomi, yang terdiri dari gaji/upah/insentif dan jaminan sosial. Dan, (2) Segi sosial psikologi, kesempatan untuk maju, kesempatan untuk mendapatkan penghargaan, berhubungan dengan masalah pengawasan, dan berhubungan dengan pergaulan antara karyawan dengan karyawan, dan antara karyawan dengan atasan (Rivai, 2011).

\section{Kepemimpinan}

Menurut Heidjrachman (2006) pemimpin adalah sesorang yang mempunyai wewenang untuk memerintah orang lain dan didalam mengerjakan pekerjaannya untuk mencapai tujuan yang telah di tetapkan dengan bantuan orang lain. Sedangkan Ishak dan Hendri (2006) berpendapat bahwa kepemimpinan (leadership) adalah kemampuan seseorang untuk menguasai atau mempengaruhi orang lain atau masyarakat yang berbeda-beda menuju pencapaian tertentu.

Sifat-sifat kepemimpinan menurut Edwin (2006) diantaranya (1) kemampuan dalam kedudukannya sebagai pengawas; (2) kebutuhan akan prestasi dalam pekerjaan; (3) kecerdasan; (4) ketegasan; (5) kepercayaan diri; (6) inisiatif; (7) keberanian mengambil keputusan; (8) kemampuan mendengar saran-saran; (9) adaptabilisasi dan fleksibilitasi; (10) ketegasan dalam bertindak.

Ada tiga gaya kepemimpinan menurut Gonzally (2006), yaitu: (1) Kepemimpinan Otoriter, kepemimpinan yang kekuasaan atau wewenang sebagian besar mutlak tetap berada pada pimpinan atau kalau pimpinan itu menganut sistem sentralisasi wewenang, pengambilan keputusan dan kebijaksanaan hanya ditetapkan sendiri oleh pemimpin, bawahan tidak diikutsertakan untuk memberikan saran, ide, dan pertimbangan. (2) Kepemimpinan Partisipasif, kepemimpinan dilakukan secara persuasif, menciptakan kerjasama yang serasi menumbuhkan loyalitas, dan partisipasi para bawahan. Pemimpin memotivasi bawahan agar merasa ikut memiliki 
perusahaan. Dan (3) Kepemimpinan Delegatif, merupakan pemimpin yang mendelegasikan wewenang kepada bawahan agak lengkap.

\section{Fokus pada Konsumen}

Fokus pada konsumenadalah upaya untuk memahami, menjalin hubungan yang erat dan mencari masukan-masukan dari pelanggan secara teratur Morrow (2006). Dalam pendekatan TQM, kosumen dan pemasok ada di dalam dan di luar organisasi. Pelanggan eksternal adalah orang yang membeli dan menggunakan produk perusahaan. Pemasok eksternal adalah orang diluar organisasi yang menjual bahan mentah/bahan baku, informasi, atau jasa kepada organisasi.

Tjiptono dan Anastasia (2006) mengemukakan bahwa kepuasan pelanggan dapat memberikan beberapa manfaat sebagai berikut: (1) Hubungan antara perusahaan dan para pelanggannya menjadi harmonis; (2) Memberikan dasar yang baik bagi pembelian ulang; (3) Dapat mendorong terciptanya loyalitas pelanggan; (4) Membentuk suaturekomendasi yang menguntungkan bagi perusahaan; (5) Reputasi perusahaan menjadi baik di mata pelanggan; dan, (6) Laba yang diperoleh dapat meningkat.

\section{Pemberdayaan Karyawan}

Tjiptono dan Anastasia (2006) mengatakan pelibatan karyawan adalah suatu proses untuk mengikutsertakan para karyawan pada semua level organisasi dalam pembuatan keputusan dan pemecahan masalah. Keputusan akan menjadi lebih baik dengan adanya masukan dari setiap pihak yang dipengaruhi oleh keputusan tersebut.

Menurut Tjiptono dan Anastasia (2006), ada beberapa hal yang bisa didapatkan dari pemberdayaan karyawan: (1) Mampu memotivasi diri; (2) Menyediakan pengertian dan keahlian yang lebih dan partisipasi ini akan membuat lebih berkomitmen untuk melakukan yang terbaik; (3) Percaya mampu mengerjakan pekerjaan; (4) Menunjukan inisiatif yang lebih dan ketekunan dalam mengejar tujuan organisasi; (5) Mempunyai otonomi dan kemampuan untuk mengerjakan pekerjaan yang bermakna yang dapat berdampak pada organisasi; (6) Produktif dan menghasilkan pelayanan konsumen yang lebih baik; (7) Lebih puas dan efikasi diri meningkat; (8) Mengambil tanggung jawab untuk bertindak; dan, (9) Berusaha memecahkan masalah dan tidak menyalah-nyalahkan.

\section{Manajemen Proses}

Suatu proses dapat didefenisikan sebagai integrasi sekuensial dari orang, material, metode, dan mesin atau peralatan, dalam suatu lingkungan guna menghasilkan nilai tambah output untuk pelanggan Gaspersz (2014). Suatu proses mengkonversi input terukur kedalam output terukur melalui sejumlah langkah sekuensial yang terorganisasi.

Terdapat empat kelompok orang yang terlibat dalam operasi dan perbaikan proses yaitu: (1) Pelanggan; (2) Kelompok Kerja; (3) Pemasok; dan, 
(4) Pemilik. Tenner dan De Toro dalam Gaspersz (2014) mengemukakan suatu model perbaikan proses yang terdiri dari enam langkah, sebagai berikut: (1) Mendefenisikan masalah dalam bentuk proses; (2) Identifkasi dan dokumen proses; (3) Mengukur performansi; (4) Memahami mengapa suatu masalah dalam konteks proses terjadi; (5) Mengembangkan dan menguji ide-ide; dan, (6) Implementasi solusi dan evaluasi.

\section{Hipotesis Penelitian}

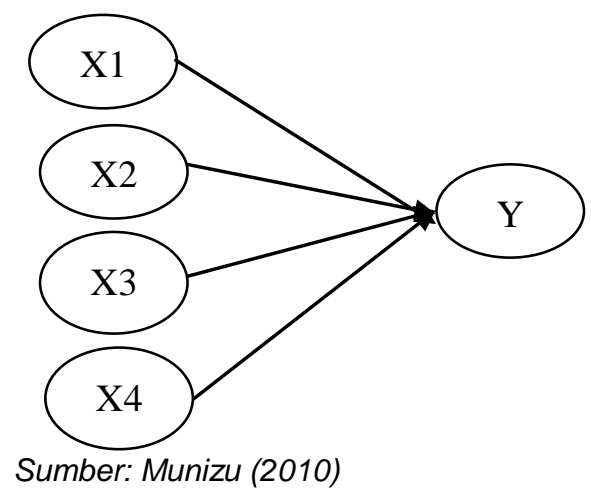

Gambar 1. Model Penelitian

Adapun hipotesis yang diuji dalam penelitian ini adalah:

1. Pengaruh kepemimpinan, fokus pada konsumen, pemberdayaan karyawan, dan manajemen prosesterhadap kepuasan kerja karyawan

2. Kepemimpinan berpengaruh terhadapkepuasan kerja karyawan.

3. Fokus pada konsumen berpengaruh terhadapkepuasan kerja karyawan.

4. Pemberdayaan karyawan berpengaruh terhadapkepuasan kerja karyawan.

5. Manajemen proses berpengaruh terhadap kepuasan kerja karyawan.

6. Terdapat Perbedaan kepuasan kerja karyawan yang dilihat dari faktor gender

\section{METODE PENELITIAN}

Penelitian ini dilakukan pada PT Telkomsel Area Pekanbaru yang berada di Pekanbaru. Populasi dalam penelitian ini adalah semua karyawan tetap di PT Telkomsel Area Pekanbaru yang berjumlah 123 orang. Penelitian ini mengambil sampel sejumlah sampel 94 responden yang diambil dengan menggunakan rumus slovin.

Jenis dan sumber data yang digunakan adalah data primer yaitu data yang didapat dari sumber pertama baik berupa hasil dari wawancara atau hasil pengisian kuisioner dan data sekunder yaitu data yang telah diolah dan telah tersaji serta telah terdokumentasi.

Teknik pengumpulan data dilakukan dengan cara interview yaitu pengumpulan data dengan cara mengadakan wawancara langsung dengan pimpinan dan sebagian karyawan. 


\section{Metode Analisi Data}

Metode analisis data dalam penelitian ini adalah metode regresi linear bergandayang digunakan untuk mengetahui pengaruh dari variabel independen terhadap variabel dependen. Maka model rumus regresi linear berganda sebagai berikut:

$$
Y=a+b_{1} X_{1}+b_{2} X_{2}+b_{3} X_{3}+b_{4} X_{4}+e
$$

\section{Defenisi Operasional Variabel}

Untuk lebih jelasnya mengenai operasional variabel berdasarkan indikator masing-masing variabel sebagai berikut:

Indikator Kepuasan Kerja Karyawan ( $\mathrm{Y}$ ) adalah kepuasan terhadap gaji, kepuasan terhadap promosi, kepuasan terhadap rekan sekerja, kepuasan terhadap pekerjaan itu sendiri dan kepuasan terhadap atasan.

Sedangkan indikator Kepemimpinan $\left(\mathrm{X}_{1}\right)$ adalah mempertimbangkan kebutuhan semua pihak termasuk konsumen dan karyawan, membuat visi yang jelas pada masa depan, menentukan tujuan dan target yang menantang, kemampuan berkomunikasi dan menginspirasikan, mendorong dan mengenali kontribusi semua karyawan.

Indikator Fokus Pada Konsumen $\left(\mathrm{X}_{2}\right)$ adalah tanggap dan memenuhi kebutuhan konsumen, memberikan produk dan layanan sesuai dengan yang diharapkan konsumen, mengelola hubungan dengan konsumen secara sistematis.

Indikator Pemberdayaan Karyawan $\left(\mathrm{X}_{3}\right)$ adalah keterlibatan karyawan, pengakuan atas eksistensi karyawan, menghargai kemampuan karyawan, pendidikan karyawan dan pengembangan karir karyawan.

Indikator Manajemen proses $\left(\mathrm{X}_{4}\right)$ adalah perencanaan, pengorganisasian, pengkoordinasian dan pengontrolan sumberdaya.

\section{HASIL DAN PEMBAHASAN}

Berdasarkan analisis data diketahui bahwa PT Telkomsel Pekanbaru lebih banyak mempekerjakan karyawannya yang berjenis kelamin perempuan, karena dari segi pekerjaan tidak terlalu membutuhkan fisik atau tenaga yang kuat dalam pengerjaannya. Sedangkan dari segi usia sebagian besar karyawan berumur 31-40 tahun. Sehingga dari dapat disimpulkan bahwa perusahaan telah mempekerjakan orang-orang yang sudah berpengalaman. Selanjutnya perusahaan lebih banyak mempekerjakan karyawan lulusan Strata 1 karena dalam proses kerjanya dibutuhkan karyawan yang mempunyai pendidikan lebih tinggi dankeahlian khusus. Masa kerja karyawan terbanyak adalah 0-10 tahun yaitu 58\%. Hal ini berarti dari sisi pengalaman sudah cukup memadai dan semangat kerja serta kemampuan fisik masih stabil. 


\section{Uji Validitas}

Kegunaan uji validitas untuk mengetahui sejauh mana ketepatan dan kecermatan suatu instrumen pengukuran dalam melakukan fungsi ukurnya yaitu agar data yang diperoleh bisa relevan/sesuai dengan tujuan diadakannya pengukuran tersebut.Suatu instrumen dikatakan valid jika pernyataan pada suatu instrumen mampu untuk mengungkapkan sesuatu yang akan diukur oleh kuesioner tersebut. Uji validitas dilakukan dengan membandingkan nilai $r$ hitung dengan $r$ tabel pada taraf signifikansi $5 \%$ untuk uji 2 sisi. Jika $r$ hitung $>r$ tabel maka alat ukur yang digunakan dinyatakan valid dan sebaliknya, jika $r$ hitung $\leq r$ tabel maka alat ukur yang digunakan tidak valid. Nilai $r$ tabel dapat diperoleh dengan rumus $\mathrm{df}=\mathrm{N}-2=94-2=92$ (lihat tabel $r$ dengan $\mathrm{df} 94$ ) $=0,203$. Berdasarkan hasil olahan data, diketahui bahwa semua item pernyataan yang digunakan dalam penelitian ini adalah valid.

\section{Uji Reliabilitas}

Pengujian ini bertujuan untuk mengetahui tingkat keandalan dari instrument pernyataan yang valid. Pengujian dilakukan dengan menggunakan cronbach's alpha. Batasan nilai dalam uji adalah 0,60. Jika nilai reliabilitas kurang dari 0,60 maka nilainya kurang baik. Nilai reliabilitas dalam uji ini dapat dilihat pada kolom Reliabilitiy Statistics (Cronbach's Alpha)

Tabel 1. Hasil Uji Reliabilitas Instrument

\begin{tabular}{lcc}
\hline \multicolumn{1}{c}{ Variabel } & Cronbach's Alpha & Ket. \\
\hline Kepuasan Kerja Karyawan & 0,839 & Reliabel \\
Kepemimpinan & 0,805 & Reliabel \\
Fokus Konsumen & 0,641 & Reliabel \\
Pemberdayaan Karyawan & 0,740 & Reliabel \\
Manajemen Proses & 0,837 & Reliabel \\
\hline
\end{tabular}

Berdasarkan hasil uji reliabilitas yang telah dilakukan seluruh penyataan yang digunakan untuk mengukur variabel yang ada dalam penelitian ini telah Iolos uji reliabilitas. Hasil penelitian ini menyatakan bahwa keseluruhan penyataan tersebut konsisten mengukur variabel penelitian.

\section{Uji Normalitas Data}

Pengujian normalitas bertujuan untuk menguji apakah dalam model regresi, variabel pengganggu atau residual memiliki distribusi normal, bila asumsi ini dilanggar maka uji statistik menjadi tidak valid untuk jumlah sampel kecil mengetahui pola distribusi dari suatu data hasil penelitian.

Berdasarkan Gambar 2 data yang menyebar ke semua daerah kurva, berbentuk simetris atau lonceng maka berdistribusi normal. Dan pada Gambar 3 dapat dilihat grafik Normal Probability P-Plot.Dari gambar tesebut terlihat titik-titik mengikuti garis diagonal. Model regersi memenuhi asumsi normalitas. 


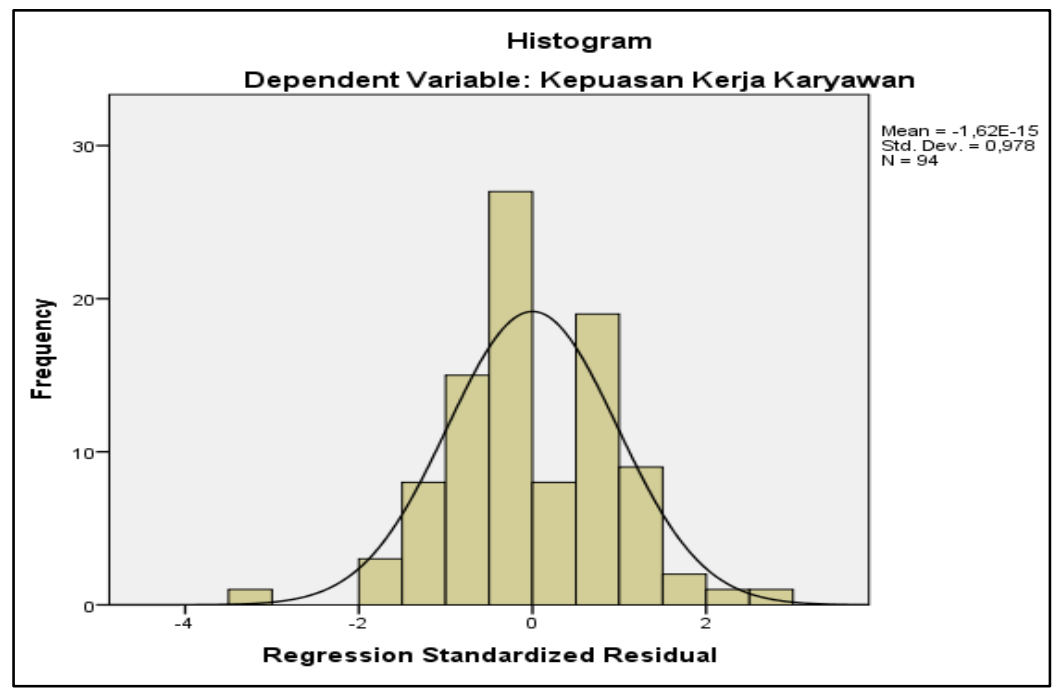

Gambar 2. Kurva Histogram

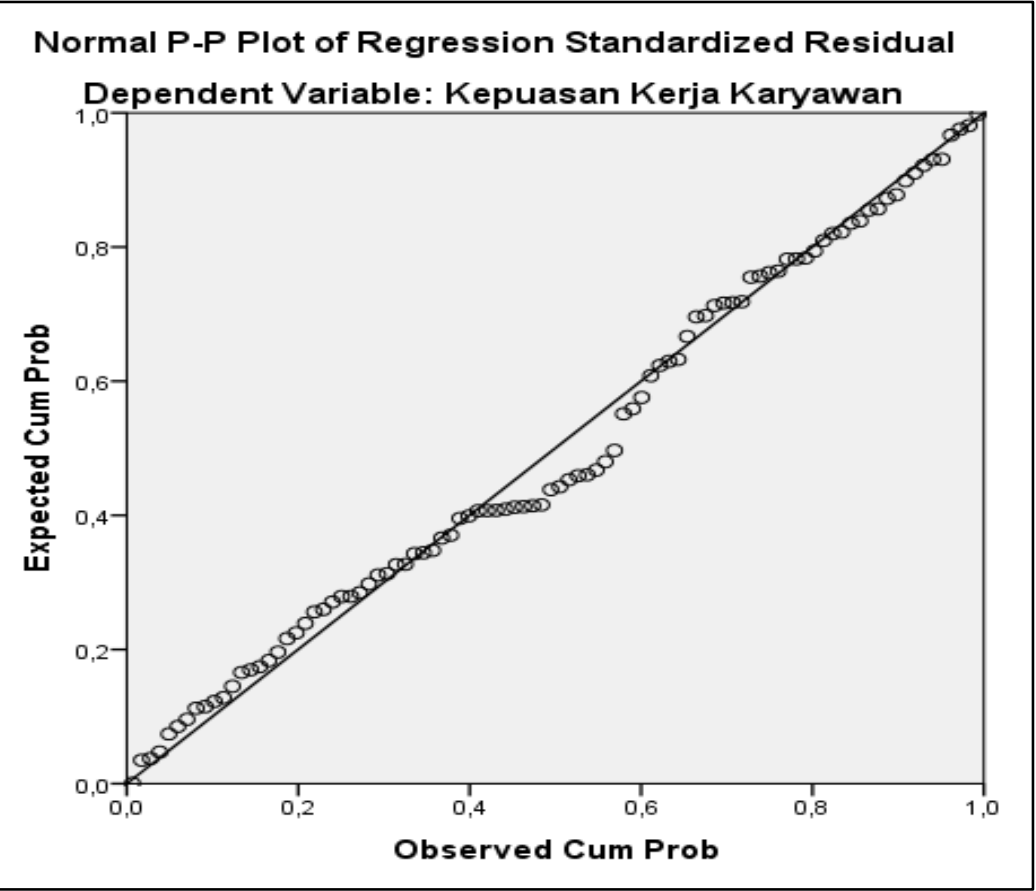

Gambar 3. Grafik Normal P-P Plot

\section{Uji Heterokedastisitas}

Berdasarkan hasil penelitian ini telah membuktikan bahwa terdapat adanya tidak heterokedastisitas, sehingga menunjukkan bahwa tidak adanya terjadinya perbedaan antara variasi dari residual loyalitas kerja karyawan yang diakibatkan oleh variabel penelitian yang mempengaruhinya. Berdasarkan grafik pada Gambar 4, terlihat bahwa titik-titik tidak membentuk pola tertentu dan menyebar diatas dan dibawah pada sumbu Y. Jadi, dapat disimpulkan bahwa model regresi dalam penelitian ini tidak terdapat heteroskedastisitas. 


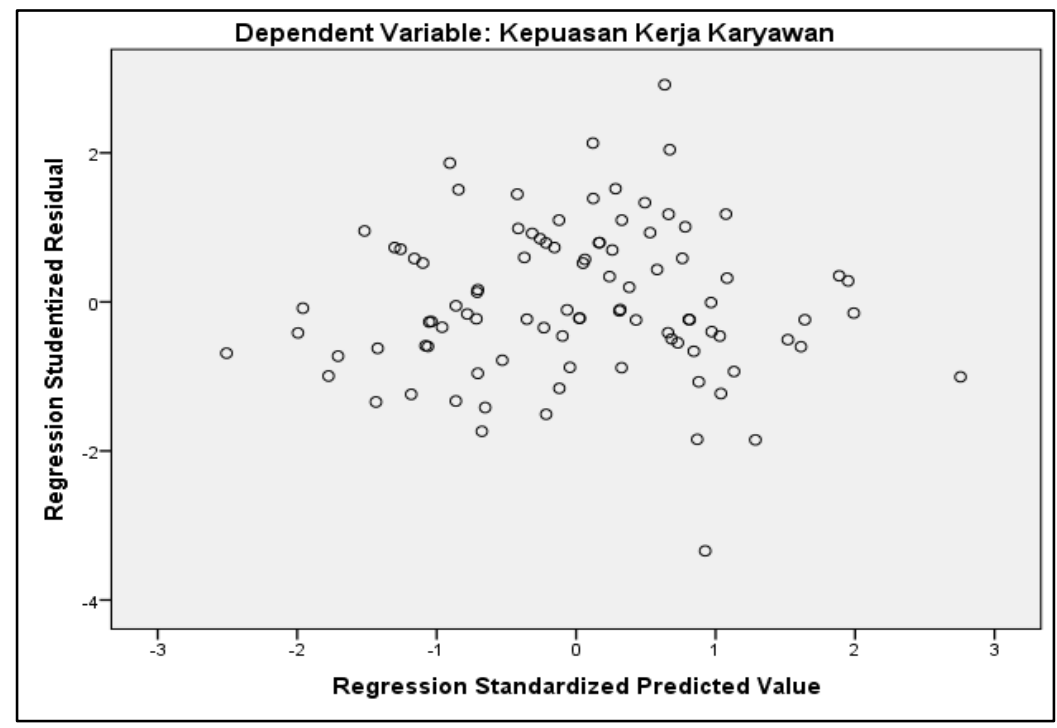

Gambar 4. Scatterplot

\section{Uji Multikolerasi}

Untuk melihat adanya gejala multikolinearitas dapat dilakukan dengan menguji koefisien korelasi parsial variabel-variabel bebasnya melalui metrik korelasi, bila korelasinya signifikan maka antar variabel bebas tersebut terjadi multikolinearitas.

Berdasarkan hasil pengolahan data dengan melihat nilai VIF dengan formula $=$ VIF $=\frac{1}{1-R^{2}}=\frac{1}{\text { Toleransi }}$, dimana Kepemimpinan $\left(\mathrm{X}_{1}\right)$ sebesar, 1,387 Fokus Konsumen $\left(X_{2}\right)$ sebesar1,582, Pemberdayaan Karyawan $\left(X_{3}\right)$ sebesar 1,741 , dan manajemen proses $\left(X_{4}\right)$ sebesar1,946. Sehingga dapat disimpulkan bahwa ketiga variabel bebas tersebut tidak terdapat multikonearitas karena nilai VIF nya lebih kecil dari 10. Maka dapat dinyatakan tidak terjadi gejala multikolinearitas dalam model regresi.

\section{Uji Autokorelasi}

Pengujian ini dilakukan untuk menguji apakah dalam suatu model regresi linier ada korelasi antara kesalahan pengguna pada periode t dengan kesalahan pada periode $\mathrm{t}-1$.

Nilai $\mathrm{DW}=1,960$ nilai ini akan dibandingkan dengan nilai tabel signifikan $5 \%$ dengan $(\mathrm{n}=94)$ dan jumlah variabel independent $(\mathrm{k}=4)$ maka diperoleh $\mathrm{dL}=$ 1,576 dan $\mathrm{Du}=1,753$.

Karena nilai $\mathrm{DW}=1,960$ lebih besar dari batas atas (dU) yakni 1,753 dan kurang dari (4-dU) 4-1,753 = 2,247 sehingga disimpulkan tidak terdapatautokorelasi. 


\section{Hasil Regresi Berganda}

Untuk mengetahui bagaimana pengaruh faktor-faktor tersebut dapat dilihat dengan menggunakan analisis regresi linear berganda, sehingga diperoleh persamaan seperti berikut ini:

Tabel 2. Hasil Pengujian Regresi

\begin{tabular}{|c|c|c|c|c|c|}
\hline 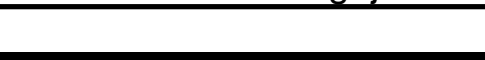 & \multicolumn{3}{|c|}{ Coefficients $^{\mathrm{a}}$} & \multirow{3}{*}{$\mathrm{t}$} & \multirow{3}{*}{ Sig. } \\
\hline & \multicolumn{2}{|c|}{$\begin{array}{c}\text { Unstandardized } \\
\text { Coefficients }\end{array}$} & $\begin{array}{l}\text { Standardized } \\
\text { Coefficients }\end{array}$ & & \\
\hline & $\mathrm{B}$ & Std. Error & Beta & & \\
\hline (Constant) & 2,190 & 1,429 & & 1,532 & ,129 \\
\hline Kepemimpinan & , 154 & 075 & , 179 & 2,039 &, 044 \\
\hline FokusKonsumen & ,473 & 143 & ,310 & 3,301 & ,001 \\
\hline PemberdayaanKaryawan & ,237 & , 102 & ,230 & 2,332 & ,022 \\
\hline Manajemen Proses & ,258 & ,117 & ,229 & 2,195 & ,031 \\
\hline
\end{tabular}

Tabel 2 menunjukkan bahwa persamaan regresi linear berganda dalam penelitian ini adalah sebagai berikut:

$$
\begin{aligned}
& Y=a+b_{1} X_{1}+b_{2} X_{2}+b_{3} X_{3}+b_{4} X_{4}+e \\
& Y=2,190+0,154 K+0,473 F K+0,237 P K+0,258 M P+e
\end{aligned}
$$

Arti angka-angka dalam persamaan regresi diatas:

a. Nilai konstanta (a) sebesar 2,190. Artinya adalah apabila variabel independen diasumsikan nol (0), maka kepuasan kerja karyawan sebesar 2,190 .

b. Nilai koefisien regresi variabel kepemimpinan sebesar 0,154. Artinya adalah bahwa setiap peningkatan kepemimpinan sebesar 1 satuan maka akan meningkatkan kepuasan kerja karyawan sebesar 0,154 dengan asumsi variabel lain tetap.

c. Nilai koefisien regresi variabel fokus konsumen sebesar 0,473. Artinya adalah bahwa setiap peningkatan fokus konsumen sebesar 1 satuan makaakan meningkatkan kepuasan kerja karyawan sebesar 0,473 dengan asumsi variabel lain tetap.

d. Nilai koefisien regresi variabel pemberdayan karyawan sebesar 0,237. Artinya adalah bahwa peningkatan pemberdayaan karyawan sebesar 1 satuan maka akan meningkatkan kepuasan kerja karyawan sebesar 0,237 denganasumsivariabel lain tetap.

e. Nilai koefisien regresi variabel manajemen proses sebesar 0,258. Artinya adalah bahwa setiap peningkatan manajemen proses sebesar 1 satuan makaakan meningkatkan kepuasan kerja karyawan sebesar 0,258 dengan asumsi variabel lain tetap.

f. Standar error (e) merupakan variabel acak dan mempunyai distribusi probabilitas yang mewakili semua faktor yang mempunyai pengaruh 
terhadap $\mathrm{Y}$ tetapi tidak dimasukkan dalam persamaan.

\section{Pembahasan Hasil Penelitian}

\section{Pengaruh Kepemimpinan Terhadap Kepuasan Kerja Karyawan}

Hasil uji yang dilakukan menunjukkan bahwa kualitas kepemimpinan memiliki pengaruh langsung terhadap kepuasan kerja karyawan. Artinya semakin baik kualitas kepemimpinan maka kepuasan kerja karyawan akan semakin baik. demikian pula sebaliknya, semakin buruk kualitas kepemimpinan yang diterapkan maka kepuasan kerja karyawan akan semakin buruk. Kontribusi langsung yang diberikan kepemimpinan terhadap kepuasan kerja karyawanini menjelaskan bahwa perubahan kepuasan kerja karyawan dipengaruhi oleh kualitas kepemimpinan. Hal ini sejalan dengan penelitian yang dilakukan oleh Munizu (2010), dan Raharjo dan Nafisah (2006) dimana semua penelitian tersebut menemukan bahwa kepemimpinan berpengaruh terhadap kepuasan kerja karyawan.

\section{Pengaruh Fokus Pada Konsumen Terhadap Kepuasan Kerja Karyawan}

Hasil pengujian yang dilakukan menunjukkan bahwa fokus pada konsumen memiliki pengaruh langsung terhadap kepuasan kerja karyawan.Penelitian ini menyimpulkan bahwa semakin fokus perusahaan terhadap kebutuhan konsumen,maka kepuasan kerja karyawan akan semakin baik. Demikian pula sebaliknya, semakin kurang fokus perusahaan terhadap kebutuhan konsumen maka kepuasan kerja karyawan akan semakin buruk. Kontribusi langsung yang diberikan fokus pada konsumen terhadap kepuasan kerja karyawan ini menjelaskan bahwa perubahan kepuasan kerja karyawan dipengaruhi oleh fokus pada konsumen yang baik dengan besarnya pengaruh yang diberikan.Hal ini sejalan dengan penelitian yang dilakukan oleh Munizu (2010) yang menunjukkan hasil bahwa variabel fokus pada konsumen berpengaruh terhadap kepuasan kerja karyawan.

\section{Pengaruh Pemberdayaan Karyawan Terhadap Kepuasan Kerja Karyawan}

Uji statistik yang dilakukan menunjukkan bahwa pemberdayaan karyawan memiliki pengaruh terhadap kepuasan kerja karyawan. Penelitian ini menyimpulkan bahwa semakin optimal pemberdayaan karyawan yang diterapkan perusahaan maka kepuasan kerja karyawan akan semakin baik. Demikian pula sebaliknya, semakin kurang optimal pemberdayaan karyawan yang diterapkan perusahaan maka kepuasan kerja karyawan akan semakin buruk. Kontribusi langsung yang diberikan pemberdayaan karyawan terhadap kepuasan kerja karyawan ini menjelaskan bahwa perubahan kepuasan kerja karyawan dipengaruhi oleh optimalisasi pemberdayaan karyawan dengan besarnya pengaruh yang diberikan.

\section{Pengaruh Manajemen Proses terhadap Kepuasan Kerja Karyawan}

Pengujian pengaruh manajemen proses terhadap kepuasan kerja karyawan juga menunjukkan hasil yang signifikan, atau dengan kata lain 
Hipotesis ke-5 medapat dukungan. Penelitian ini menyimpulkan bahwa semakin baik manajemen proses yang dijalankanperusahaan maka kepuasan kerja karyawan juga akan semakin baik. Demikian pula sebaliknya, semakin buruk manajemen proses yang dijalankan perusahaan maka kepuasan kerja karyawan akan semakin buruk. Kontribusi langsung yang diberikan manajemen proses terhadap kepuasan kerja karyawan ini menjelaskan bahwa perubahan kepuasan kerja dipengaruhi oleh manajemen proses yang baik.

\section{Perbedaan Kepuasan Kerja Karyawan Berdasarkan Gender}

Berdasarkan hasil pengolahan data diketahui bahwa tidak ada perbedaan kepuasan kerja karyawan laki-laki dan perempuan, atau dengan kata lain tingkat kepuasan kerja karyawan adalah sama, walupun diakui ada perbedaan kepuasan kerja diantara keduanya, yaitu dimana kepuasan kerja laki-laki sebesar 14,8343 dan kepuasan kerja perempuan sebesar 15,5066, dan selisih 0,7307. Hasil tersebut menunjukkan kepuasan kerja rata-rata karyawan wanita lebih besar dibandingkan kepuasan kerja laki-laki, namun perbedaan tersebut tidaklah signifikan.

\section{SIMPULAN DAN SARAN}

\section{Simpulan}

Dari hasil analisa yang telah diuraikan, dapat ditarik kesimpulan bahwa:

1. Pengujian atas kekuatan model yang digunakan dalam penelitian menunjukkan bahwa model yang digunakan telah layak untuk mengamati faktor yang mempengaruhi kepuasan kerja karyawan berupa kepemimpinan, fokus pada konsumen, pemberdayaan karyawan dan manajemen proses.

2. Kepemimpinan berpengaruh terhadap kepuasan kerja karyawan artinya. Artinya semakin baik kepemimpinan maka akan semakin baik pula kepuasan karyawan terhadap pekerjaannya. Sebaliknya apabila kepemimpinan yang ada diperusahaan tidak diperbaiki maka akan menurunkan kepuasan kerja karyawan. Hal ini dapat terlihat dari kepemimpinan dimana menurut karyawan, pimpinan perusahaan sepenuhnya belum mampu memberikan arahan yang jelas dan dapat dimengerti oleh bawahan.

3. Fokus pada konsumen berpengaruh terhadap kepuasan kerja karyawan. Artinya semakin perusahaan fokus terhadap kebutuhan konsumen maka kepuasan karyawan terhadap pekerjaan akan semakin meningkat. Sebaliknya apabila fokus pada konsumen yang ada diperusahaan tidak diperbaiki maka akan menurunkan kepuasan kerja karyawan. Hal ini dapat dilihat dari fokus pada konsumen dimanamenurut karyawan, perusahaan sepenuhnya belum mampu mengidentifikasi kebutuhan konsumen.

4. Pemberdayaan karyawan berpengaruh terhadap kepuasan kerja karyawan. Artinya apabila perusahaan dapat mengelola dan memberdayakan karyawan dengan baik maka kepuasan kerja karyawan akan dapat tercapai. 
Sebaliknya apabila pemberdayaan karyawan yang ada diperusahaan tidak diperbaiki maka akan menurunkan kepuasan kerja karyawan. Hal ini dapat terlihat dari pemberdayaan karyawan dimana menurut karyawan, perusahaan belum sepenuhnya mampu memberikan pendidikan yang memadai bagi peningkatan skill karyawan.

5. Manajemen proses berpengaruh terhadap kepuasan kerja karyawan. Artinya semakin baik proses manajemen dalam perusahaan maka akan semakin baik pula dampaknya terhadap kepuasan kerja karyawan. Sebaliknya apabila manajemen proses tidak diperbaiki maka akan dapat menurunkan kepuasan kerja karyawan. Hal ini dapat terlihat dari dalam manajemen proses dimana menurut karyawan perusahaan belum mampu mengorganisasikan pembagian pekerjaan karyawan dengan baik.

6. Kepuasan kerja karyawan laki-laki dan perempuan relatif tidak berbeda, walupun secara rata-rata kepuasan kerja karyawan wanita lebih tinggi dari kepuasan kerja karyawan laki-laki.

\section{Saran}

Berdasarkan pada beberapa kesimpulan, maka dapat diberikan saran sebagai berikut:

1. Untuk memaksimalkan kepemimpinan, diharapkan pimpinan perusahaan agar selalu memberikan arahan yang jelas dan dapat dimengerti oleh bawahan.

2. Untuk memaksimalkan fokus pada konsumen, diharapkan perusahaan agar dapat mengidentifikasi kebutuhan konsumen dan adanya masukan-masukan dari pelanggan dapat memberikan perubahan cara kerja perusahaan sehingga dapat memberikan kepuasan kerja pada karyawan dengan pencapaian target yang diharapkan.

3. Untuk memaksimalkan pemberdayaan karyawan, maka diharapkan kepada perusahaan agarmemberikanpendidikan yang memadai bagi peningkatan skill karyawan dan mengikut sertakan para karyawan pada semua level organisasi dalam pembuatan keputusan dan pemecahan masalah.

4. Untuk memaksimalkan manajemen proses, maka diharapkan kepada perusahaan agar mengorganisasikan pembagian pekerjaan karyawan dengan baik sehingga pembagian kerja setiap karyawan lebih fokus dan jelas serta dapat bekerja dengan maksimal dan sesuai dengan prosedur. Dengan berpedoman kepada SOP maka pengorganisasian pembagian kerja karyawan dapat diatasi dengan baik.

\section{Keterbatasan}

Beberapa batasan yang terdapat di dalam penelitian ini yang memungkinkan untuk dilakukan pengembangan pada penelitian selanjutnya, adalah:

1. Penelitian ini hanya menjadikan perusahaan PT Telkomsel sebagai objek penelitian, sehingga kesimpulan yang dibuat dari penelitian ini dapat saja tidak dapat diterapkan pada perusahaan lainnya. 
2. Penelitian ini hanya menggunakan empat variable yang dinilai mempengaruhi tingkat kepuasan kerja karyawan, yaitu kepemimpinan, fokuspadakonsumen, pemberdayaan karyawan dan manajemen proses. Sementara diakui kepuasan kerja karyawan tidak hanya dipengaruhi oleh keempat faktor tersebut.

3. Dalam penelitian ini tidak dilakukan pemisahan fungsi dan tingkatan karyawan dalam aktvitas pekerjaan, sehingga sangat memungkinkan adanya pengaruh fungsi dan tingkatan karyawan dalam aktivitas pekerjaan juga mempengaruhi kepuasan kerja karyawan tersebut.

\section{DAFTAR PUSTAKA}

Anoraga. 2009. Manajemen Bisnis. Semarang: PT Rineka Cipta.

Edwin. 2006. Manajemen Personalia. Jakarta: Erlangga.

Gaspersz, V. 2014. Production Planning and Inventory Control. Jakarta: PT Gramedia Pustaka Umum.

Gonzally. 2006. Production Planning and Inventory Control. Jakarta: PT Gramedia Pustaka Umum.

Heidjrachman. 2006. Manajemen Personalia. Yogyakarta: BPFE.

Ishak dan Hendri. 2006. Manajemen Sumber Daya Manusia Untuk Perusahaan. Jakarta: Erlangga.

Munizu, M. 2010. Praktik Total Quality Management (TQM) Dan Pengaruhnya Terhadap Kinerja Karyawan (Studi Pada PT. Telkom Tbk. Cabang Makassar). Jurnal Manajemen Dan Kewirausahaan. Vol.12. No. 2. Hal. 185-194.

Morrow. 2006. Work Commitment Among Departement of Transfortation Employees, Profesional Notes, Review of Public Personnel Administration, Vol 8. No.3. Hal. 96-104.

Raharjo dan D. Nafisah. 2006. Analisis Pengaruh Gaya Kepemimpinan Terhadap Kepuasan Kerja, Komitmen Organisasi Dan Kinerja Karyawan (Studi Empiris pada Departemen Agama Kabupaten Kendal dan Departemen Agama Kota Semarang). Jurnal Studi Manajemen \& Organisasi. Vol 3 No 2.

Rivai. 2011. Manajemen Sumber Daya Manusia Untuk Perusahaan. Jakarta: PT. Raja Grafindo Persada.

Tjiptono dan Anastasia. 2006. Manajemen Sumber Daya Manusia Untuk Perusahaan: Dari Teori Ke Praktik. Jakarta: Raja Grafindo.

Wibowo. 2010. Manajemen Kinerja, edisi ketiga. Jakarta: Rajawali Pers. 